\title{
Following the evidence, from coronavirus to terrorism response
}

\author{
Tom Moberly UK editor
}

The BMJ

The emergence of a novel coronavirus has led China to impose travel restrictions around Wuhan and other cities (doi:10.1136/ bmj.m349). Yet, as G James Rubin and Simon Wessely point out (doi:10.1136/bmj.m313), we don't not know whether the potential benefits of mandatory mass quarantine outweigh the psychological costs of such an intervention to the people affected. Elisabeth Mahase summarises what we know so far about the virus and its effects (doi:10.1136/bmj.m308); clearly there is much we are yet to understand.

Researchers studying this novel infection and its epidemiology are working in a landscape that differs radically, in terms of time pressure and timelines, from that in the 15 year study that assessed the soy intake of 93000 people (doi:10.1136/bmj.m34). Soy products are widely consumed in Asian countries, especially Japan, and some countries also include soy products in their dietary guidelines. Yet it is unclear whether these products are associated with specific health benefits. The observational study by Ryoko Katagiri and colleagues finds that a higher intake of fermented soy was associated with lower mortality.

We also report this week on pelvic examinations and other screening tests for cervical cancer. As Kim Painter reports (doi:10.1136/bmj.m290), most teenage girls do not need these tests, but new figures show that many girls and women in the US undergo them anyway.

Another area of suboptimal practice is the response to terrorist attacks. In their essay Claire Park and colleagues argue that we may be able to increase survival after terrorist attacks by adopting the standard military practice of allowing first aid while the immediate threat is dealt with (doi:10.1136/bmj.m298). In our annual appeal this year we supported WaterAid, a charity that brings safe drinking water and toilets to millions of people worldwide (doi:10.1136/bmj.16703). We'd like to thank readers for their generous support for the appeal, which has raised more than $£ 40000$. If you'd like to donate you still can, at www. wateraid.org/uk/donate/the-bmj.

Finally, over the past few weeks we have trialled a new daily email that alerts recipients to the latest content on bmj.com. Tell us what you think of the new format: if you don't already receive the "Today on bmj.com" email you can sign up in the "My account" section of bmj.com.

Read our latest coverage of the coronavirus outbreak at bmj.com/coronavirus.

Published by the BMJ Publishing Group Limited. For permission to use (where not already granted under a licence) please go to http://group.bmj.com/group/rights-licensing/ permissions 